\title{
Study of Heavy Metal Distribution in Medicinal Plant Basil
}

\section{Vinod Jena ${ }^{1 *}$ and Sapana Gupta ${ }^{2}$}

${ }^{1}$ Department of Chemistry, ICFAI University, Raipur, India

${ }^{2}$ Central Institute of Technology, Abhanpur, Raipur, India

\begin{abstract}
Medicinal plants and their extracts deserve special attention because of the important influence they have to human health. There are easily contaminated with metals during growth, development and processing. The aim of this study was to achieve the quantitative determination of metallic elements $(\mathrm{Cu}, \mathrm{Cr}, \mathrm{Cd}, \mathrm{Mn}, \mathrm{Zn}, \mathrm{Pb})$ in medicinal plants basil using ICP-AES. Metal content in the powdered medicinal plants was in descending order: $\mathrm{Zn}>\mathrm{Mn}>\mathrm{Cu}>\mathrm{Cr} ; \mathrm{Pb}$ and $\mathrm{Cd}$ were present in minor amounts. Analysis of plant infusions showed transfer of heavy metals during extraction procedure. Monitoring the content of mineral elements in medicinal plants and their boiling water extracts is of high importance because some heavy metals in large quantities in the body may have a toxic effect.
\end{abstract}

Keywords: Basil; Heavy metals; Translocation factor; Bioaccumulation factor

\section{Introduction}

Basil has been planted as a popular culinary and medicinal herb from ancient time until now and the leaves and flowers have been used for the treatment of headaches, coughs, diarrhea, worms and kidney malfunctions, as well as for its carminative, galactagogue, stomachic and antispasmodic properties [1-4]. The use of herbal medicines has been on the rise in recent years due to their low prices and lack of awareness of people about their side effects. There is a common concept among people that herbal medicines have no side effects and that "being natural in origin, herbs are safe". These medicines are popular because of long-term effectiveness against many chronic disorders [5].

The metals i.e. As, $\mathrm{Se}, \mathrm{Cd}, \mathrm{Hg}, \mathrm{Pb}$, etc. are very toxic to humans and environment and plants are suggested as potential biosorbents for trace metals removal from the soil. In plants, several groups (i.e. hydroxyl, carboxyl, carbonyl, sulfhydryl, thioether, sulfonate, amine, amide, imine, imidiazole, phosphonate, phosphodiester groups, etc.) are suggested the complexation of metal ions. The World Health Organization (WHO 1998) recommends that medicinal plants which form the raw materials for the finished products may be checked for the presence of heavy metals, pesticides, bacterial or fungal contamination. Herbal plants have been used to remove heavy metals. However, there is an inherent health risk associated with many of these plants due to presence of contaminating HMs. The medicinal herbs are a potential source of toxic metal exposure for man and animals [6-13].

In the present work, the biosorption pattern of HMs in the various plant parts (i.e. flower, leaf, stem and root) of different basil species: namely sweet basil (Ocimum basilicum) black basil (Ocimum sanctum) and dwarf basil (Ocimum minumum) are discussed.

\section{Materials and Methods}

\section{Collection of sample}

Different parts of basil (i.e. leave, stem, root and seed) and rhizospheric soil were collected from Bhilai (latitude: $21^{\circ} 12^{\prime} 36^{\prime \prime} \mathrm{N}$, longitude: $\left.81^{\circ} 22^{\prime} 47^{\prime \prime} \mathrm{E}\right)$ near Raipur, capital of Chhattisgarh state, central India). The plants sample was washed thoroughly with distilled water, dried in a shed, compressed into a powder with the help of a manual grinder and the particles $<1 \mathrm{~mm}$ sieved out.

\section{Sequential extraction process for preparation of sample}

The HMs present in different geochemical fractions of the soil was determined by the sequential extraction scheme. The theory behind SEP is that the most mobile metals are removed in the first fraction and continue in order of decreasing of mobility. All SEPs facilitate fractionation. Tessier et al. named these fractions exchangeable, carbonate bound, $\mathrm{Fe}$ and $\mathrm{Mn}$ oxide bound, organic matter bound, and residual. These are also often referred to in the literature as exchangeable, weakly absorbed, hydrous-oxide bound, organic bound, and lattice material components, respectively. $1 \mathrm{~g}$ of soil sample is placed in a $50 \mathrm{~mL}$ tube. The sample is exposed to reagents and shaken. Each fraction is separated from the supernatant by centrifugation at $10,000 \mathrm{rpm},(12,000$ gravity $)$ for $30 \mathrm{~min}$. The supernatant is collected for lab analysis. The sediment is rinsed with $8 \mathrm{~mL}$ of deionized water (DIW) and centrifuged again. For the fourth fraction, a $1 \mathrm{~g}$ (dry weight) sample is exposed to $12 \mathrm{~mL}$ of $5: 1 \mathrm{HF}^{-} \mathrm{HClO}_{4}$ acid mixture and evaporated to near dryness. A 10:1 $\mathrm{HF}-\mathrm{HClO}_{4}$ acid mixture is added to the sample and again evaporated to near dryness followed by $1 \mathrm{~mL}$ of $\mathrm{HClO}_{4}$, evaporated until white fumes are visible. The final digestion is performed with $12 \mathrm{~N} \mathrm{HCl}$ and diluted to $25 \mathrm{~mL}$ [10].

\section{Chemical and reagents}

The AR grade (E. Merck, Germany) chemicals were used for digestion of the soil and plant samples. The ICP multi-element (23 elements) standard (E. Merck, Germany) was used for preparation of the calibration curve.

\section{Chemical analysis}

An instrument: inductively coupled plasma-atomic emission spectrometry (ICP-AES) Ultima-2 from Jobin Yvon, France equipped with parallel flow nebulizer and cyclonic spray chamber was used for the monitoring of the heavy metals (i.e. $\mathrm{Cr}, \mathrm{Mn}, \mathrm{Fe}, \mathrm{Ni}, \mathrm{Cu}, \mathrm{Zn}$,

*Corresponding author: Vinod Jena, Department of Chemistry, ICFAI University Raipur, India, E-mail: jenavinod02@gmail.com

Received October 25, 2012; Accepted November 28, 2012; Published November 30, 2012

Citation: Jena V, Gupta S (2012) Study of Heavy Metal Distribution in Medicinal Plant Basil. J Environ Anal Toxicol 2:161. doi:10.4172/2161-0525.1000161

Copyright: ( 2012 Jena $\mathrm{V}$, et al. This is an open-access article distributed unde the terms of the Creative Commons Attribution License, which permits unrestricted use, distribution, and reproduction in any medium, provided the original author and source are credited. 
and $\mathrm{Pb}$ ). Atomic Absorption Spectrophotometer (AAS) GBC 932 Australia equipped with Hydride Generator (HG-3000) was used for the determination of the total arsenic and mercury using sodium borohydride for reduction. The standard addition method was used for the quality control and data validation of the method.

\section{Metal contents in coarse particulates}

The distribution of coarse particulate matter $\left(\mathrm{PM}_{10}\right)$ in the ambient air of the study area in Nov. 2004 was obtained by using high volume air sampler over the quartz filter paper. The mass concentration $(n=3)$ of $\mathrm{PM}_{10}$ in the ambient air was found to be $310 \mu \mathrm{g} \mathrm{m}^{-3}$. The sample was digested with acids $\left(\mathrm{HCl}+\mathrm{HClO}_{4}+\mathrm{HF}\right)$ and analyzed with flame atomic absorption spectrophotometer (AAS).

\section{Results and Discussion}

\section{Metal contents in soil}

The sequential extraction procedures were employed to investigate the distribution and chemical fraction of heavy metals retained in tested soils. Four extractants i.e. hot water, $\mathrm{NaHCO}_{3}, \mathrm{NaOH}$ and $\mathrm{HCl}$ were used to determine soluble, exchangeable, bound to hydroxide of $\mathrm{Fe}$ and $\mathrm{Al}$ and carbonate fraction, respectively. Acid mixture i.e. $\mathrm{HNO}_{3}$, $\mathrm{HClO}_{4}$ and $\mathrm{HF}$ was used to determine the total metal contents. The total contents $\left(\mathrm{mg} \mathrm{kg}^{-1}\right)$ of the metal i.e. $\mathrm{Cr}$ (828), $\mathrm{Mn}$ (1480), $\mathrm{Ni}$ (110), $\mathrm{Cu}$ (1240), $\mathrm{Zn}$ (61), As (13), $\mathrm{Hg}$ (4.3), $\mathrm{Pb}$ (545) in the rhizosphere soil is ranged from $4.3-27165 \mathrm{mg} \mathrm{kg}^{-1}$. Their sum of total extractable fraction in the hot water, $\mathrm{NaHCO}_{3}, \mathrm{NaOH}$ and $\mathrm{HCl}$ are found in increasing order: $\mathrm{Cr}(4.6) \approx \mathrm{Mn}(4.9) \approx \mathrm{Ni}(5.0)<\mathrm{As}(9.4)<<\mathrm{Pb}(25.1) \approx \mathrm{Hg}(25.2)<\mathrm{Cu}$ $(36.5)<\mathrm{Zn}(55.0 \%)$. Relatively higher fractions $(>1.0 \%)$ of metals i.e. $\mathrm{Cr}$, $\mathrm{Hg}$ was found to be present in the soluble forms. A significant fraction of metals i.e. As, $\mathrm{Hg}, \mathrm{Pb}$ was found to exist in the exchangeable (coordinated to organic acid and other anions) forms. A higher fraction of metals i.e. $\mathrm{As}, \mathrm{Cu}, \mathrm{Hg}$, and $\mathrm{Pb}$ were found in the bound form with oxide and sulfide of $\mathrm{Fe}$ and Al. A major fraction of all metals were found to be present in the carbonate forms in increasing order: As $\approx \mathrm{Cr}<\mathrm{Ni}$ $\approx \mathrm{Mn}<\mathrm{Hg}<\mathrm{Pb}<\mathrm{Fe}<\mathrm{Cu}<\mathrm{Zn}$ in the soil. The $\mathrm{NaOH}$ and $\mathrm{HCl}$ leachable contents of the HMs and the total contents in the soil solution have fair correction $\left(\mathrm{R}^{2} \geq+0.71\right)$. The particle contents of $\mathrm{Mn}, \mathrm{Fe}, \mathrm{Cu}, \mathrm{Zn}$ and $\mathrm{Pb}$ in the $\mathrm{PM}_{10}$ were $0.05,2.21,0.94,0.05$ and $0.01 \%$, respectively.

\section{Metal contents in different varieties of Basil}

The total mean concentration of the HMs in flower and leaf of three varieties of basil: sweet, black and dwarf are summarized tables 1 and 2. The distribution order for the most of the HMs in three species have similar trend, and found to be in increasing order: $\mathrm{Hg} \approx$ $\mathrm{As}<\mathrm{Ni}<\mathrm{Cr}<\mathrm{Cu}<\mathrm{Zn}<\mathrm{Mn}<<\mathrm{Fe}$ with higher mean values for leaf. Among them, generally, the sweet basil showed the highest HMs contents. However, flower, leaf and stem portions of the plant contained higher concentrations of the trace metals than root due to the fallout of atmospheric pollutants through dry as well as wet deposition. Their contents are found in decreasing order: leaf $>$ flower $>$ stem $>$ root. The highest HMs contents in sweet basil are observed may be due to the highest biomass production as well as the highest growth rate [14-17]. Two coefficients, biological absorption coefficient (BAC) i.e. plant to soil metal ratio and concentration factor (CF) i.e. plant to water soluble metal ratio are used in the present work [18]. The value BAC and CF depend on the physical and chemical composition of the soil, type of basil species and their morphology. The $\mathrm{CF}$ and $\mathrm{BAC}$ trends observed are $\mathrm{Cr}<\mathrm{As} \leq \mathrm{Hg}<<\mathrm{Cu} \approx \mathrm{Pb}<\mathrm{Ni}<\mathrm{Zn}<\mathrm{Fe}<\mathrm{Mn}$; and $\mathrm{Cr}<\mathrm{Cu} \approx \mathrm{Pb}<\mathrm{Mn}<\mathrm{Fe}$ $\approx \mathrm{Ni}<\mathrm{As}<\mathrm{Hg}<\mathrm{Zn}$, respectively. The translocation factor (TLF) is a content of metal in root to leaf, and the TLF values of many metals (i.e.

\begin{tabular}{|l|l|l|l|l|l|l|}
\hline \multirow{2}{*}{ Metal } & \multicolumn{2}{l|}{$\begin{array}{l}\text { Sweet Basil } \\
\text { (Ocimum basilicum) }\end{array}$} & \multicolumn{2}{l|}{$\begin{array}{l}\text { Black Basil } \\
\text { (Ocimum sanctum) }\end{array}$} & \multicolumn{2}{l|}{$\begin{array}{l}\text { Dwarf Basil } \\
\text { (Ocimum minumum) }\end{array}$} \\
\cline { 2 - 6 } & Flower & Leaf & Flower & Leaf & Flower & Leaf \\
\hline $\mathbf{A s}$ & 0.17 & 2.1 & 0.15 & 1.8 & 0.12 & 1.2 \\
\hline $\mathbf{C r}$ & 20.3 & 21.4 & 10.7 & 24.4 & 9.4 & 7.8 \\
\hline $\mathbf{M n}$ & 100 & 192 & 21.4 & 267 & 30.8 & 124 \\
\hline $\mathbf{N i}$ & 11.9 & 18.6 & 2.7 & 13.2 & 2.4 & 5.7 \\
\hline $\mathbf{C u}$ & 23.7 & 29.2 & 18.7 & 21.4 & 7.4 & 15.1 \\
\hline $\mathbf{Z n}$ & 28.8 & 34.2 & 18.7 & 28.2 & 7.6 & 11.8 \\
\hline $\mathbf{H g}$ & 0.17 & 2.1 & 0.20 & 2.0 & 0.21 & 1.2 \\
\hline $\mathbf{P b}$ & 15.3 & 18.5 & 7.5 & 9.4 & 5.3 & 8.0 \\
\hline
\end{tabular}

Table 1: Metal contents in various parts of basil $\mathrm{mg} \mathrm{kg}^{-1}$ dry weight.

\begin{tabular}{|l|l|l|l|}
\hline Metal & $\begin{array}{l}\text { Sweet Basil } \\
\text { (Ocimum basilicum) }\end{array}$ & $\begin{array}{l}\text { Black Basil } \\
\text { (Ocimum sanctum) }\end{array}$ & $\begin{array}{l}\text { Dwarf Basil } \\
\text { (Ocimum minumum) }\end{array}$ \\
\hline As & 2.1 & 1.8 & 1.2 \\
\hline $\mathbf{C r}$ & 21.4 & 24.4 & 7.8 \\
\hline $\mathbf{M n}$ & 192 & 267 & 124 \\
\hline $\mathbf{F e}$ & 10814 & 9043 & 2465 \\
\hline $\mathbf{N i}$ & 18.6 & 13.2 & 5.7 \\
\hline $\mathbf{C u}$ & 29.2 & 21.4 & 15.1 \\
\hline $\mathbf{Z n}$ & 34.2 & 28.2 & 11.8 \\
\hline $\mathbf{H g}$ & 2.1 & 2.0 & 1.2 \\
\hline $\mathbf{P b}$ & 18.5 & 9.4 & 8.0 \\
\hline
\end{tabular}

Table 2: Metal contents in leaf $\mathrm{mg} \mathrm{kg}^{-1}$ dry weight.

As, $\mathrm{Cr}, \mathrm{Mn}, \mathrm{Fe}, \mathrm{Ni}, \mathrm{Pb}$ ) in leaf are found to be significantly high. The levels of $\mathrm{Hg}$ and $\mathrm{Pb}$ determined in the investigated plant sample were found to exceed the maximum allowable levels of $\mathrm{Hg}\left(0.05 \mathrm{mg} \mathrm{kg}{ }^{-1}\right)$ and $\mathrm{Pb}\left(1.2 \mathrm{mg} \mathrm{kg}^{-1}\right)$ by Zentrale Erfassungs- und Bewertungsstelle für Umweltchemikalien (ZEBS) [19-24].

\section{Conclusion}

The concentration of the some HMs in various parts of the basil exceeded the permissible levels. The contaminated soil, ground water and dust are expected to be major significant sources for their sorption in the basil. They can accumulate in the basil through the foliage and root system. The use of medicinal plants grown in the polluted site may be one of the dangerous potential entry pathways in humans and other animals.

\section{References}

1. Hassanpouraghdam MB, Gohari GR, Tabatabaei SJ, Reza DM (2010) Sastav etarskog ulja cvasti i listova bosiljka gajenog hidroponično. J Serb Chem Soc 75: $1361-1368$.

2. Sovljanski R, Lazic S, MaCko V, Obradovic S (1990) Herba-Hung. 29: 59-63.

3. Jordan SA, Cunningham DG, Marles RJ (2010) Assessment of herbal medicinal products: Challenges, and opportunities to increase the knowledge base for safety assessment. Toxicol Applied Pharmacol. 243: 198-216.

4. Heath HB (1981) Source book of flavour. Westport: Avi Publications 635-674.

5. Özcan M, Arslan D, Ünver A (2005) Effect of drying methods on the mineral content of basil (Ocimum basilicum L.) J Food Eng 69: 375-379.

6. Amorozo MCM (2002) Uso e diversidade de plantas medicinais em Santo Antonio do Leverger, MT, Brasil. Acta Botanica Brasilica 16: 189-203.

7. Krug H, Chizzola R (1989) Acta Hortic, 249.

8. Pethkar AV, Gaikaiwari RP, Paknikar KM (2001) Biosorptive removal of contaminating heavy metals from plant extracts of medicinal value. Curr Sci 80: 1216-1219.

9. Cataldo DA, Wildung RE (1978) Soil and plant factors influencing the accumulation of heavy metals by plants. Environ Heath Perspect 27: 149-159. 
Citation: Jena V, Gupta S (2012) Study of Heavy Metal Distribution in Medicinal Plant Basil. J Environ Anal Toxicol 2:161. doi:10.4172/21610525.1000161

10. Listow SA, Petrow NW (1990) Dtsch. Apoth-Ztg 130: 2629-2630.

11. Chow PYT, Chua TH, Tang KF (1995) Dilute acid digestion procedure for the determination of lead, copper and mercury in traditional Chinese medicines by atomic absorption spectrometry. Analyst 120: 1221-1223.

12. Sovljanski R, Lazic S, Macko V, Obradovic S (1990) Heavy Metal Content In Medicinal And Spice Plants Cultivated In Yugoslavia.

13. Al-Saleh FS, Chudasama S (1994) Trace metal concentrations in the medicinal plants of the flora of Bahrain. Toxicol Environ Chem 46: 1-2.

14. Dunbabin DW, Tallis GA, Popplewell PY, Lee RA (1992) Lead poisoning from Indian herbal medicine (Ayurveda). Med J Australia 157: 835-836.

15. Runyoro D, Ngassapa O, Vagionas K, Aligiannis N, Graikou K, et al. (2010) Chemical composition and antimicrobial activity of the essential oils of four Ocimum species growing in Tanzania. Food Chem 119: 311-316.

16. Tabuti JR (2008) Herbal medicines used in the treatment of malaria in Budiope county, Uganda. J Ethnopharmacol 116: 33-42.

17. Kim YU, Kim KW, Lee JU, Lee JS, Cook J (2002) Environ. Geochem. Health 24: $215-227$.
18. Singh R, Singh DP, Kumar N, Bhargava SK, Barman SC (2010) Accumulation and translocation of heavy metals in soil and plants from fly ash contaminated area. J Environ Biol 31:421-430.

19. Reid R, Hayes J (2003) Mechanisms and control of nutrient uptake in plants. Int Rev Cytol 229: 73-114.

20. Kahle H (1993) Response of roots of trees to heavy metals. Environ Exp Bot 33: 99-119.

21. Garbisu C, Hernández-Allica J, Barrutia O, Alkorta I, Becerril JM (2002) Phytoremediation: a technology using green plants to remove contaminants from polluted areas. Rev Environ Health 17: 173-188.

22. Ernst $E$ (2002) Toxic heavy metals and undeclared drugs in Asian herbal medicines. Trends Pharm Sci 23: 136-139.

23. Hall JL, Williams LE (2003) Transition metal transporters in plants. J Exp Bot 54: $2601-2613$.

24. Janick J, Whipkey A (2002) Trends in new crops and new uses. ASHS Press, Alexandria, VA. 